Toxicities of copper oxide nanomaterial and copper sulphate in early life stage zebrafish: Effects of $\mathrm{pH}$ and intermittent pulse exposure

Boyle, D

http://hdl.handle.net/10026.1/16480

10.1016/j.ecoenv.2019.109985

Ecotoxicology and Environmental Safety

Elsevier BV

All content in PEARL is protected by copyright law. Author manuscripts are made available in accordance with publisher policies. Please cite only the published version using the details provided on the item record or document. In the absence of an open licence (e.g. Creative Commons), permissions for further reuse of content should be sought from the publisher or author. 


\title{
Toxicities of copper oxide nanomaterial and copper sulphate in early life stage zebrafish: Effects of $\mathrm{pH}$ and intermittent pulse exposure
}

\author{
David Boyle, Nathaniel J. Clark, Richard D. Handy* \\ School of Biological and Marine Sciences, The University of Plymouth, Plymouth, PL4 8AA, UK
}

\section{A R T ICLE INFO}

\section{Keywords}

Copper toxicity

Early life stage

Nanoparticles

Oxidative stress

$\mathrm{pH}$

Pulse exposure

\begin{abstract}
A B S T R A C T
Effort has been made to standardise regulatory ecotoxicity tests for engineered nanomaterials (ENMs), but the environmental realism of altered water quality and/or pulse exposure to these pollutants should be considered. This study aimed to investigate the relative toxicity to early life-stage zebrafish of CuO ENMs at acid $\mathrm{pH}$ and then under pulse exposure conditions, all compared to $\mathrm{CuSO}_{4}$. At all $\mathrm{pH}$ values, $\mathrm{CuSO}_{4}$ was more toxic to zebrafish than $\mathrm{CuO}$ ENMs. Additions of $\mathrm{H}^{+}$were protective of $\mathrm{CuSO}_{4}$ toxicity, with median lethal concentrations $\mathrm{LC}_{50}$ (with 95\% confidence intervals) of: $0.36(0.33-0.40), 0.22(0.20-0.24)$ and $0.27(0.25-0.29) \mathrm{mg} \mathrm{L}^{-1}$ at $\mathrm{pH}$ 5, pH 6 and $\mathrm{pH} 7$, respectively. In contrast, the toxicity of $\mathrm{CuO}$ ENMs increased with acidity; $\mathrm{LC}_{50}$ values were: 6.6 (4.5-8.5), 19.4 (11.6-27.2) and $>100 \mathrm{mg} \mathrm{L}^{-1}$ at $\mathrm{pH} 5, \mathrm{pH} 6$ and $\mathrm{pH} 7$, respectively. The increased toxicity of the $\mathrm{CuO}$ ENMs in acid water corresponded with greater dissolution of dissolved $\mathrm{Cu}$ from the particles at low $\mathrm{pH}$, suggesting free $\mathrm{Cu}^{2+}$ ion delivery to the zebrafish was responsible for the $\mathrm{pH}$-effect. In continuous $96 \mathrm{~h}$ exposures to the substances at the $\mathrm{LC}_{10}$ values and at $\mathrm{pH}$ 6, both $\mathrm{CuSO}_{4}$ and $\mathrm{CuO}$ ENMs caused $\mathrm{Cu}$ accumulation, inhibition of $\mathrm{Na}^{+} / \mathrm{K}^{+}$-ATPase and depletions in total glutathione in zebrafish. However, two $24 \mathrm{~h}$ pulses of $\mathrm{CuSO}_{4}$ or $\mathrm{CuO}$ ENMs at the same peak concentration caused similar effects to the continuous $96 \mathrm{~h}$ exposure, despite the shorter exposure durations of the former; suggesting that the pulses were more hazardous than the continuous exposure. In conclusion, the current water quality correction for $\mathrm{pH}$ with respect to $\mathrm{Cu}$ toxicity to freshwater fish should not be applied to the nano form. Crucially, CuO ENMs are more toxic in pulse than continuous exposure and new corrections for both water $\mathrm{pH}$ and the $\mathrm{Cu}$ exposure profile are needed for environmental risk assessment.
\end{abstract}

\section{Introduction}

In regulatory toxicology, single species toxicity tests are widely used to provide the data for the environmental hazard assessment of contaminants. These tests are also used for the hazard identification of engineered nanomaterials (ENMs, Crane et al., 2008Crane et al., 2008), albeit with some modifications to improve their utility for ENMs (Handy et al., 2012). However, regulatory toxicity tests have long been criticised for a lack of environmental realism (Cairns, 1983; McCahon and Pascoe, 1990; Artigas et al., 2012; McCarty et al., 2018). One of these concerns is that regulatory tests often use steady-state concentrations of the test substance, and a prescribed $\mathrm{pH}$, dissolved oxygen, etc., which do not reflect the temporal dynamics and complexity of real pollution events (McCahon and Pascoe, 1990; Handy, 1994; Vignati et al., 2007). For example, freshwaters are chemically and temporally heterogeneous due to daily fluctuations in temperature, oxygen, $\mathrm{pH}$, rainfall, run-off from urban or agricultural land, and the inputs of pollutants (review, Handy, 1994; Ed- wards and Moore, 2014). Field measurements show variable profiles of contaminants in aquatic ecosystems (Edwards and Moore, 2014) and even the consented discharge of effluents will change according to the anthropogenic activities producing the wastes. Consequently, aquatic organisms are more likely to be exposed to single or repeated pulses of pollutants (Handy, 1994). For metals, such as $\mathrm{Cu}$ that is widely found in industrial effluents, the challenge has been to identify the relative hazard of intermittent and complex pulse exposure compared to the results of continuous exposure toxicity tests.

The effects of dissolved $\mathrm{Cu}$ on freshwater fishes have been extensively studied for several decades (see reviews by Handy et al., 1989; Grosell, 2012). This research has mainly used continuous exposures to define the lethal concentrations to fish $\left(\mathrm{LC}_{50}\right.$ range from 10 to $150 \mu \mathrm{g} \mathrm{L}{ }^{-1}$ in soft water, Handy, 2003) and the mechanistic aspects of $\mathrm{Cu}$ toxicity; including the water quality variables that alter toxicity. The mechanism of acute toxicity of dissolved $\mathrm{Cu}$ in the water column involve inhibition of the $\mathrm{Na}^{+} / \mathrm{K}^{+}$-ATPase in the fish gill, with subsequent disturbances to osmoregulation (Laurén and McDonald, 1985

\footnotetext{
* Corresponding author.

E-mail address: r.handy@plymouth.ac.uk (R.D. Handy)
} 
; Shaw et al., 2012). Water chemistry has been shown to offer some protection to fishes. For example, lower $\mathrm{pH}$ values are generally protective of fish due to competition between $\mathrm{Cu}$ and $\mathrm{H}^{+}$for binding at the gills (Cusimano et al., 1986). Exposure modelling for dissolved $\mathrm{Cu}$, such as the biotic ligand model, has therefore been able to identify the bioavailable fraction of metal that is hazardous to fish (Santore et al., 2001). This has been reflected in water quality criteria for $\mathrm{Cu}$ derived from site-specific freshwater parameters such as water hardness, $\mathrm{pH}$ and the presence of dissolved organic matter (e.g., in China, Zhang et al., 2017a; and as used by the US Environmental Protection Agency, 2007).

Whether or not dissolved $\mathrm{Cu}$ is more toxic as a pulse exposure or as a continuous exposure is dependent on the number of pulses, the peak concentration of each pulse, the average concentration or dose within each pulse profile, and the organisms used (Handy, 1994). Pulse exposure might show similar toxicity compared to continuous exposure when the sum of the pulse profile(s) happens to be similar to the continuous exposure dose, but can also show toxicity greater than that expected of the continuous exposure equivalent (Handy, 1994). For example, Bearr et al. (2006) reported the same mortality level in fathead minnow (Pimephales promelas) exposed to two $24 \mathrm{~h}$ pulses of dissolved $\mathrm{Cu}$ with a peak concentration of $40 \mu \mathrm{g} \mathrm{L}^{-1}$ within a $7 \mathrm{~d}$ period, compared to exposure to $40 \mu \mathrm{g} \mathrm{Cu} \mathrm{L}{ }^{-1}$ continuously for the entire $7 \mathrm{~d}$ duration. Thus the toxicity could be attributed to the pulse profile, not the peak concentrations that were the same in both types of exposure. Changes in physiology such as altered ventilation of the gills to decrease contaminant uptake, or increased activity of detoxification mechanisms, can mitigate the effects of continuous exposures. For example, it has been shown that 'copper-acclimated' rainbow trout (Oncorhynchus mykiss) clear plasma-Cu more effectively than non-acclimated fish (Grosell et al., 2001). However, physiological adjustment may not be initiated in response to short or infrequent pulse exposures. Crucially, the amount of time in clean water between pulses can also inform on how much $\mathrm{Cu}$ can be cleared from the body burden; and when this time is short a cumulative effect on the body burden is observed (Handy, 1992). Environmental standards derived from continuous exposures to $\mathrm{Cu}$ are therefore difficult to apply to dynamic pollution events.

For ENMs, there is an emerging literature on Cu toxicity from continuous exposure studies with fish, but intermittent, pulse exposures have not been explored. In the continuous exposure studies, copper ENMs have also been shown to affect sodium homeostasis in fish (zebrafish, Griffitt et al., 2007; trout, Shaw et al., 2012). Many of the sub-lethal effects of Cu ENMs in trout (e.g., haematology, oxidative stress, organ pathologies) have been shown to be similar to the metal salt except the aetiology of pathology of the ENMs manifested later during exposure or at higher relative concentrations (Shaw et al., 2012; Al-Bairuty et al., 2013). These similarities in the patterns of toxicity suggest that $\mathrm{Cu}$ ENMs release a dissolved fraction of metal that is toxic to the fish. Indeed, some dissolution of $\mathrm{Cu}$ from $\mathrm{Cu}$ NPs occurs in freshwater and this is increased when water $\mathrm{pH}$ is lowered (Al-Bairuty et al., 2016).

Alterations of water $\mathrm{pH}$ may also cause physiological stress in fish. Real pollution events involving pulse exposure to metals can be accompanied by dynamic changes of $\mathrm{pH}$. For example, after rainfall or snowmelt on sulphide bearing rock (Dold, 2014; Hindar and Nordstrom, 2015), runoff from roads (Zhang et al., 2016) and on soil in areas of heavy industry (Alexander et al., 2017). It is not known which variable causes the most hazard to fish; i.e., the pulse of the toxic substance, or the exposure to acid $\mathrm{pH}$. However, a reduction in water $\mathrm{pH}$ has, much like $\mathrm{Cu}$ exposure, been shown to perturb sodium balance in fish (e.g. at pH 4.0 in rainbow trout; Freda and McDonald, 1988). Such information is also not easily derived from data obtained in routine regulatory toxicity tests (e.g., OECD TG210 with fish), be- cause the test protocols prescribe a constant water chemistry during the tests. A pulse exposure protocol would therefore be a useful add-on for regulatory testing (e.g., as used for organics by Zhang et al., 2017b) and with consideration of other critical variables such as $\mathrm{pH}$.

This study aimed to explore the effects of water $\mathrm{pH}$ and intermittent pulse exposures on CuO ENM toxicity to early life stage zebrafish (Danio rerio). Zebrafish were chosen because they have utility as a test organism for ENMs (e.g., Nel et al., 2012; Lin et al., 2013; Shaw et al., 2016) and are suitable for the practical aspects of managing pulse exposures in the laboratory. Zebrafish are also acid-tolerant and survive well in acid water as low as pH 4.0 (Lewis and Kwong, 2018) by upregulating cells involved in proton secretion (Horng et al., 2009) and the tight-junction proteins involved in decreasing epithelial $\mathrm{Na}^{+}$permeability (Kwong and Perry, 2013). The study design also included a metal salt control $\left(\mathrm{CuSO}_{4}\right)$ to enable direct comparison with particle effects. A first series of experiments explored the effects of $\mathrm{pH}$ alone on the acute toxicity of CuO ENMs in media adjusted to $\mathrm{pH} 5, \mathrm{pH} 6$ and $\mathrm{pH}$ 7. Then a second series of experiments explored the effects of pulse exposure to $\mathrm{CuO}$ ENMs. For these latter experiments, a suitable acidic $\mathrm{pH}$ was selected $(\mathrm{pH}$ 6) and peak concentrations of CuO ENMs that were intended to be sub-lethal $\left(96 \mathrm{~h} \mathrm{LC}_{10}\right.$ derived from acute toxicity tests). Three pulse exposure scenarios were conducted in experiments that lasted $96 \mathrm{~h}$ with $\mathrm{CuO}$ ENMs or $\mathrm{CuSO}_{4}$ : (1) a single pulse of exposure (0-24 h) early in the development of the fish embryo and then the remaining time in clean water. This pulse was conducted to determine if exposure of zebrafish embryo to a pulse caused any effects that persisted as the animals hatched into clean water. (2) A double pulse exposure with time in clean water between the pulses (i.e., pulses at $24-48 \mathrm{~h}$ and $72-96 \mathrm{~h}$ ); and finally, (3) a continuous exposure control lasting the entire $96 \mathrm{~h}$.

\section{Methods}

\subsection{Zebrafish}

Brood stock zebrafish were maintained in conditioned Plymouth tap water. The latter had been left aerating in large drums to dechlorinate before use (water chemistry in $\mathrm{mM}$, means $\pm \mathrm{SD}, n=3: \mathrm{Ca}^{2+}$, $1.12 \pm 0.05 ; \mathrm{K}^{+}, 0.10 \pm 0.01 ; \mathrm{Mg}^{2+}, 0.14 \pm 0.01 ; \mathrm{Na}^{+}, 0.93 \pm 0.04$; $\mathrm{pH}$ 7.3; conductivity $168.3 \mu \mathrm{S} / \mathrm{cm})$. The background Cu concentration in Plymouth tap water was $4.7 \pm 0.1 \mu \mathrm{g} \mathrm{L}{ }^{-1}$. Stock fish were held in a recirculating water system at $27 \pm 1{ }^{\circ} \mathrm{C}$ and under a photoperiod of $12 \mathrm{~h}$ light and $12 \mathrm{~h}$ dark, in a dedicated approved aquarium facility at Plymouth University. Fish were fed daily on newly hatched brine shrimp Artemia spp. and TetraMin Tropical flake food (Tetra, UK). To obtain embryos, pairs of zebrafish (one male and one female) were netted from stock tanks, gently transferred to $1 \mathrm{~L}$ breeding tanks fitted with a partition to separate the fish (Tecniplast, Italy) and left overnight. The following morning, the water in the breeding tanks was refreshed, the partitions removed, and the fish allowed to spawn. After $1 \mathrm{~h}$, the adult fish were transferred back to stock tanks and all embryos from multiple spawning pairs were pooled into a single $2 \mathrm{~L}$ beaker to randomise the subsequent distribution of embryos from all fish between treatment groups. Embryos were rinsed with dechlorinated and filtered $(0.2 \mu \mathrm{m}$ VWR Complete Filtration Unit, VWR, UK) Plymouth tap water and non-fertilised eggs and debris were removed by hand with a Pasteur pipette. The Animal Welfare Ethical Review Board at Plymouth University approved all experiments with early-life stage zebrafish and in compliance with Directive 2010/63/EU and its exemptions.

\subsection{Copper oxide ENMs, $\mathrm{CuSO}_{4}$ and particle characterisation}

A $1 \mathrm{mg} \mathrm{mL}{ }^{-1}$ stock of $\mathrm{Cu}$ (as $\mathrm{CuSO}_{4}$ ) was prepared in ultrapure water (18.2 M $\Omega$, ELGA, UK) in an acid-washed volumetric flask and 
used as required. Copper oxide $(\mathrm{CuO})$ ENMs were obtained as a dry powder from PlasmaChem $\mathrm{GmbH}$ (Berlin, Germany) and were supplied as part of the Sustainable Nanotechnologies Project (SUN) funded by the EU 7th Framework Programme. Bicho et al. (2017) report additional characterisation of the material and the manufacturer's information. Stock suspensions of $\mathrm{CuO}$ ENMs were prepared fresh when needed to avoid extended periods of ENM dissolution before dosing of the exposure vessels. Primary stock suspensions of CuO ENMs were prepared in $10 \mathrm{~mL}$ acid-washed volumetric flasks at $1 \mathrm{~g} \mathrm{~L}^{-1}$ in ultrapure water and dispersed by sonication $(1 \mathrm{~h}, 50 / 60 \mathrm{~Hz}, 35$ Watts, FB15048, Fisherbrand). The primary particle sizes of CuO ENMs were confirmed by electron microscopy using suspensions prepared at $1 \mathrm{mg} \mathrm{mL}^{-1}$ and dispersed as described above. Briefly, the dispersions were dispensed on to copper grids and images collected on a JEOL JEM 1400 transmission electron microscope (JEOL, South Korea). The primary particle diameters of $n=100$ ENMs were $18.2 \pm 5.6 \mathrm{~nm}$ (mean \pm SD, $n=100$, Fig. $1 \mathrm{~A}$ ) calculated using ImageJ (http://imagej.nih.gov/ij/).

The hydrodynamic diameters and agglomeration state of the dispersions, and the settling behaviours of the ENMs, were measured over $24 \mathrm{~h}$ and in triplicate beakers per treatment. Particle behaviours were explored at pH 5, pH 6 and $\mathrm{pH} 7$ using $100 \mathrm{mg} \mathrm{L}^{-1}$ of ENMs (equivalent to $79.88 \mathrm{mg} \mathrm{Cu}$ metal $\mathrm{L}^{-1}$ ) prepared by a $\times 10$ dilution of the primary stock above in $60 \mathrm{~mL}$ of conditioned $\mathrm{pH}$-adjusted $(0.2 \mathrm{~N} \mathrm{HCl})$ Plymouth tap water. The behaviours of the ENMs were also analysed in ultrapure water for reference. The concentration of $\mathrm{CuO}$ ENMs was chosen to match the top concentration used in the acute exposures (see section 2.4) and was also high enough to ensure sufficient particles were in suspension for robust measurement of hydrodynamic diame- ters and agglomeration state of the dispersions with Nanoparticle Tracking Analysis (NTA, NanoSight LM10, Malvern Instruments, Malvern, UK). Measurements were made over $24 \mathrm{~h}$ to match the duration between media renewal in exposures with zebrafish. For measurements of both settling behaviour and agglomeration state of the ENMs, $1 \mathrm{~mL}$ samples were withdrawn from immediately beneath the surface of the media to avoid disturbing the unstirred dispersions and to ensure measurements were made only on ENMs remaining in suspension. For NTA, water samples were taken at 0 and $24 \mathrm{~h}$, only. The background concentrations of natural particles in filtered Plymouth tap water were $0.14 \pm 0.07 \times 10^{8}$ particles $\mathrm{mL}^{-1}$. No particles were detected in the ultrapure water. To measure the rate of sedimentation, an extended sampling series was followed with $1 \mathrm{~mL}$ samples taken to measure total $\mathrm{Cu}$ concentrations remaining in suspension at $0,1,3,6$ and $24 \mathrm{~h}$. Concentrations of $\mathrm{Cu}$ in the samples were measured in acidified samples diluted in ultrapure water to a final concentration of $5 \% \mathrm{HNO}_{3}$ as described in section 2.4.

The dissolution of the CuO ENMs was measured by dialysis in conditioned Plymouth tap water at different $\mathrm{pH}$ values and in ultrapure water to aid the interpretation of the ecotoxicity experiments (see below). Due to logistical constraints, the dissolution analyses were performed at $20{ }^{\circ} \mathrm{C}$ (room temperature). The dissolution measurements were conducted in triplicate using previously acid-washed beakers that were rinsed in ultrapure water. Briefly, the $\mathrm{pH}$ of the tap water was adjusted to $\mathrm{pH} 5,6$ and 7 with $0.2 \mathrm{M} \mathrm{H}_{2} \mathrm{SO}_{4}$. Dialysis tubing was cut $(n=3$ / treatment) to $2.5 \mathrm{~cm} \times 15 \mathrm{~cm}$ lengths and was washed overnight in tap water according to the manufacturer's instructions (12 kDa cut-off, Sigma, UK). Then, $3 \mathrm{~mL}$ of a stock of CuO ENMs at $1 \mathrm{mg} \mathrm{mL}^{-1}$ in ultrapure water (dispersed as described above)
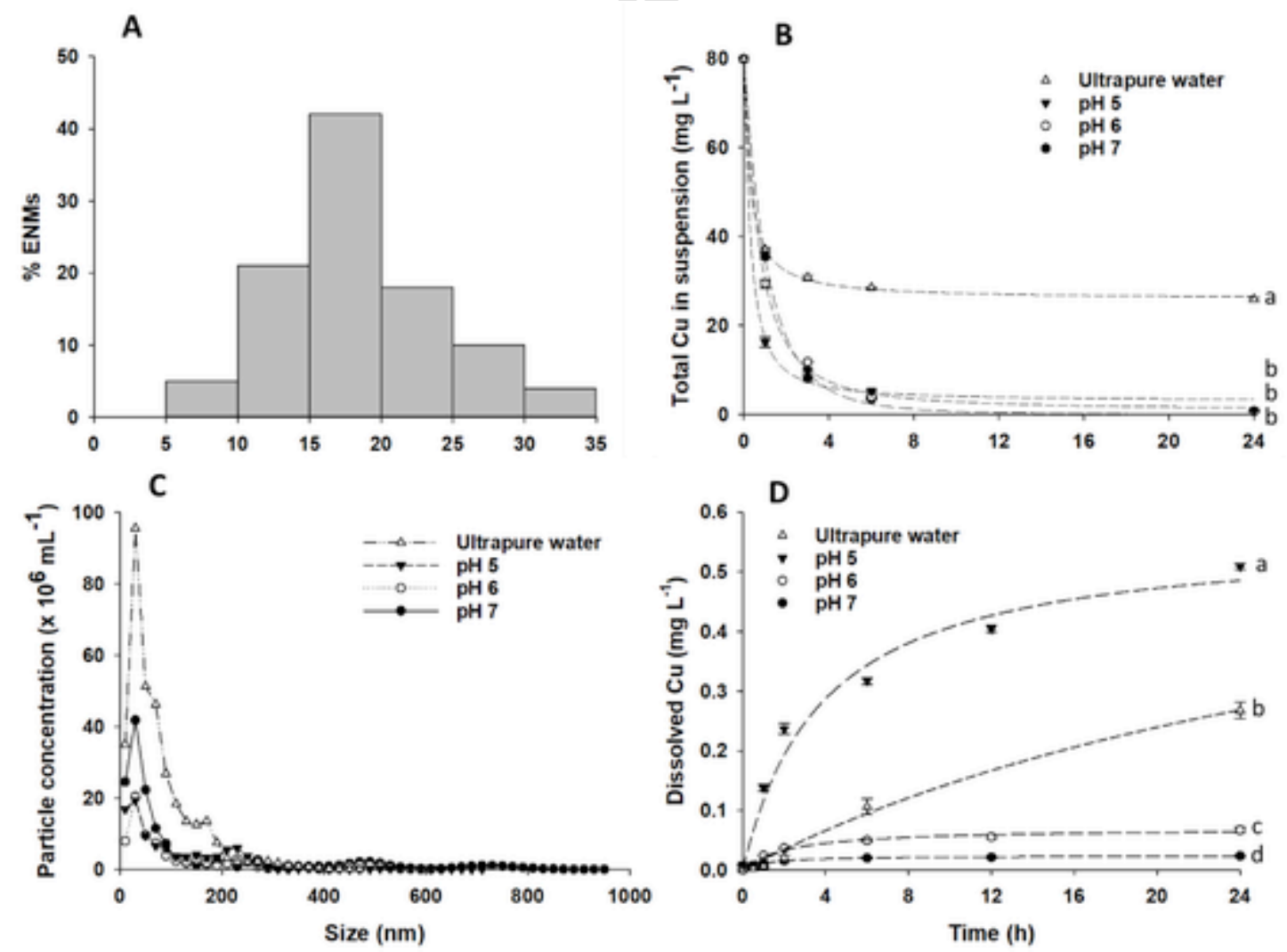

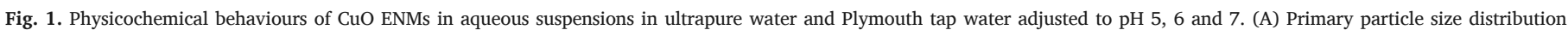

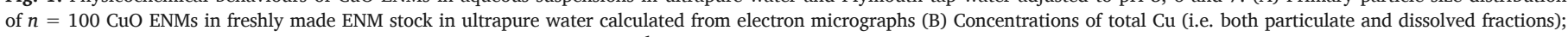

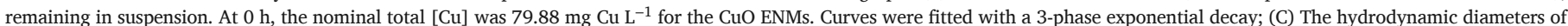

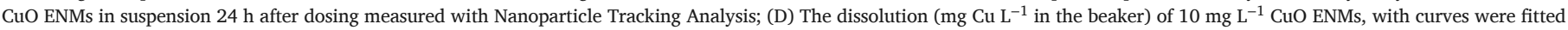

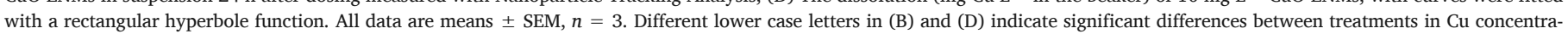
tions at $24 \mathrm{~h}$ (one-way ANOVA, $p<0.05$ ). 
were pipetted into the dialysis bags. The end of the tubing was sealed and the dialysis bag then immersed in $297 \mathrm{~mL}$ of the exposure media (1 vol ultrapure water: 9 vol of Plymouth tap water). After equilibration on the bench in air, the ultrapure water was $\mathrm{pH}$ 5.73. Beakers were placed on to an orbital shaker and gently rocked for $24 \mathrm{~h}$. At 0 (before adding dialysis bags), 0.5, 1, 2, 3, 6, 12 and $24 \mathrm{~h}$, water samples $(2.5 \mathrm{~mL})$ were taken from outside the dialysis bags and immediately acidified with $0.5 \mathrm{~mL}$ of concentrated $\mathrm{HNO}_{3}$. A water sample at $12 \mathrm{~h}$ was not collected from the ultrapure water treatment group. Samples were then diluted with ultrapure water (final concentration $5 \% \mathrm{HNO}_{3}$ ) and stored prior to metal analysis (see section 2.4). Samples of the ENMs from within the dialysis tubing were also collected for visual analysis via electron microscopy. There were no apparent changes in morphology of the CuO ENMs following $\mathrm{pH}$ treatments (Supplementary Fig. S1).

\subsection{The effect of water $\mathrm{pH}$ on the acute toxicities of $\mathrm{CuSO}_{4}$ or $\mathrm{CuO}$ ENMs}

To inform on dosimetry, acute toxicity curves were generated at different $\mathrm{pH}$ values (see Supplementary Fig. S2). The $96 \mathrm{~h}$ median lethal concentrations $\left(\mathrm{LC}_{50}\right.$ ) of $\mathrm{Cu}$ as $\mathrm{CuSO}_{4}$, or $\mathrm{CuO}$ ENMs, were calculated for zebrafish exposed in Plymouth tap water at $\mathrm{pH} \mathrm{5,} 6$ and 7, and the estimated $\mathrm{LC}_{10}$ used for experiments. Cleaned embryos at approximately $2 \mathrm{~h}$ post fertilisation (hpf) were transferred to individual wells on a 48-well plate ( $n=1$ embryos well ${ }^{-1}$ ) containing $900 \mu \mathrm{L}$ of tap water adjusted to $\mathrm{pH} 5,6$ or 7. Plymouth tap water was $\mathrm{pH}$-adjusted with $0.2 \mathrm{M} \mathrm{H}_{2} \mathrm{SO}_{4}$ in a $2 \mathrm{~L}$ beaker and then dispensed into wells. The volume of acid added to water was low and adjustment of $2 \mathrm{~L}$ Plymouth tap water to $\mathrm{pH} 5.0$ required approximately $1 \mathrm{~mL} 0.2 \mathrm{M} \mathrm{H}_{2} \mathrm{SO}_{4}$. Each well was then spiked with $100 \mu \mathrm{L}$ of ultrapure water containing either $\mathrm{CuSO}_{4}$ or dispersed $\mathrm{CuO}$ ENMs at the required concentrations. The exposure series for each material included eleven concentrations of $\mathrm{CuSO}_{4}$ or $\mathrm{CuO}$ ENMs at each $\mathrm{pH}$ and appropriate controls (controls received $100 \mu \mathrm{L}$ of ultrapure water i.e. no added $\mathrm{Cu}$ ). Addition of the materials did not alter the $\mathrm{pH}$ of the media. The concentrations used were based on observations from preliminary range-finding experiments and were $0.1,0.15,0.2,0.25$, $0.3,0.35,0.4,0.45,0.5,0.6$ and $0.8 \mathrm{mg} \mathrm{L}^{-1} \mathrm{Cu}$ as $\mathrm{CuSO}_{4}$ and 1, 2, 5, $10,20,30,40,50,60,80$ and $100 \mathrm{mg} \mathrm{L}^{-1}$ of CuO ENMs. Unless otherwise stated, data for the ENMs are shown as mass concentration of $\mathrm{CuO}$ per unit volume and not normalised to the concentration of $\mathrm{Cu}$ metal in the particle. This is because the dissolution rates of ENMs were relatively low and therefore $\mathrm{CuO}$ ENMs were the dominant form of $\mathrm{Cu}$ in water throughout ENM exposures, and this approach better reflects the study goal of understanding particle toxicity. At each concentration and at each $\mathrm{pH}, n=8$ embryos were exposed. Every $24 \mathrm{~h}$ during the $96 \mathrm{~h}$ exposure, the numbers of dead (those with no heartbeat) and hatched larvae were scored under a binocular microscope. To maintain the exposures and relevant $\mathrm{pH}$, every $24 \mathrm{~h}$ each embryo or larva was carefully transferred to new plates with Pasteur pipettes; taking care to minimise the transfer of any old media. Each well was then re-dosed with $\mathrm{CuSO}_{4}$ and $\mathrm{CuO}$ ENMs at appropriate concentrations and as described above. This entire procedure was repeated on three separate occasions and with three different batches of embryos for a total of $n=24$ embryos for each $\mathrm{pH}$ and material concentration combination.

\subsection{Effects of $\mathrm{CuSO}_{4}$ and $\mathrm{CuO}$ ENMs at low dose $\mathrm{LC}_{10}$ pulse exposure at pH 6}

The effects of pulse exposures to low concentrations $\left(\mathrm{LC}_{10}\right)$ of the $\mathrm{CuO}$ ENMs or the equivalent sublethal dose of $\mathrm{CuSO}_{4}$ in zebrafish was investigated at $\mathrm{pH} 6$ only. A comparison of effects at all the different $\mathrm{pH}$ values used in the previous experiment was not performed because the $\mathrm{LC}_{50}$ for $\mathrm{CuO}$ ENMs at $\mathrm{pH} 7$ exceeded the highest dose used in the acute toxicity tests $\left(100 \mathrm{mg} \mathrm{L}^{-1}\right)$ and therefore these data would have greater uncertainty in the $\mathrm{LC}_{10}$ estimation compared to other treatment groups. Preliminary data indicated that although no mortality or hatch inhibition was observed in control zebrafish at $\mathrm{pH} 5$ and $\mathrm{pH} 6$ compared to $\mathrm{pH} 7$, the activity of $\mathrm{Na}^{+} / \mathrm{K}^{+}$-ATPase was significantly elevated and total glutathione (GSH) was significantly decreased in embryos in acid water at pH 5 (details of the assays are described below; Supplementary Fig. S3). Thus pH 6 was selected as the most relevant $\mathrm{pH}$ for the pulse experiment.

The total test period for sub-lethal exposures was $96 \mathrm{~h}$. Embryos were exposed to $\mathrm{CuSO}_{4}$ or $\mathrm{CuO}$ ENMs at the $96 \mathrm{~h} \mathrm{LC}_{10}$ of each substance with re-dosing every $24 \mathrm{~h}$ where relevant. The different sub-lethal pulse exposures were as follows: (i) early exposure from 0 to $24 \mathrm{~h}$ followed by transfer to clean water until $96 \mathrm{~h}$ to determine any latent effect of the pulse as the embryos developed into juveniles; (ii) intermittent exposure to two pulses of $\mathrm{CuO}$ ENMs or $\mathrm{CuSO}_{4}$, characterised by periods in clean water (no added $\mathrm{Cu}$ at $0-24 \mathrm{~h}$ and $48-72 \mathrm{~h}$ ) interspersed with two periods of exposure to $\mathrm{Cu}$ (i.e., at $24-48 \mathrm{~h}$ and $72-96 \mathrm{~h}$ ); and (3), continuous exposure to $\mathrm{CuSO}_{4}$ or $\mathrm{CuO}$ ENMs from 0 to $96 \mathrm{~h}$. Therefore, embryos receiving early or intermittent exposures were exposed to 0.25 and 0.5 of the total $\mathrm{Cu}$ dose received by embryos in the continuous exposure. Unexposed controls maintained for $96 \mathrm{~h}$ in clean media adjusted to $\mathrm{pH} 6$ were also included in the experimental run. To guarantee sufficient tissue for biochemistry and metal analyses at $96 \mathrm{~h}$, embryos were exposed in quadruplicate as groups of $n=60$ embryos in each of $n=4$ beakers per treatment containing $60 \mathrm{~mL}$ media (i.e., 240 animals/treatment). The preparation of the exposure media and the stock suspensions of the materials were prepared as described in section 2.2 . The hatch rate and mortalities in each beaker were scored every $24 \mathrm{~h}$ and debris and dead zebrafish were removed prior to transferring the live zebrafish to facilitate re-dosing in previously unused clean cups every $24 \mathrm{~h}$ where the media was then refreshed.

At the end of the $96 \mathrm{~h}$ exposure, sub-samples of the embryos/larvae were collected for total $\mathrm{Cu}$ accumulation and biochemistry (pools of 10-15 embryos). Both $\mathrm{CuSO}_{4}$ and $\mathrm{CuO}$ ENMs caused hatch inhibition in embryos (controls were $>98 \%$ hatched at $96 \mathrm{hpf}$ ). To avoid incidentally carrying-over high concentrations of exposure media and chorion-associated $\mathrm{Cu}$ that may otherwise interfere with subsequent assays (Ong et al., 2014a), embryos were manually dechorionated with fine watchmaker's forceps (Fisher, UK), washed in $3 \times$ clean exposure media and $1 \times$ ultrapure water. Larvae were then sampled for total $\mathrm{Cu}$ concentrations (see below) or snap frozen in liquid $\mathrm{N}_{2}$ and then stored at $-80{ }^{\circ} \mathrm{C}$ for measurements of the activity of $\mathrm{Na}^{+} / \mathrm{K}^{+}$-ATPase and the concentration of GSH. A small sub-set of chorionated embryos $(n=3-5$ per beaker) were retained to measure the total embryo associated $\mathrm{Cu}$ fraction including the chorion.

Total $\mathrm{Cu}$ concentrations in zebrafish, water samples from exposures taken immediately after dosing and again after $24 \mathrm{~h}$, and water samples from the dissolution and settling measurements (see section 2.2), were determined by inductively coupled plasma mass spectrometry (ICP-MS, Thermo Electron Corporation X-Series II quadruple) or inductively coupled plasma optical emission spectroscopy (ICP-OES, Varian 725-ES, Agilent Technologies Inc.). Zebrafish were digested in $0.5 \mathrm{~mL} \mathrm{HNO}_{3}$ (68\%, Primar-Plus Trace Analysis Grade, Fisher, UK) for $1 \mathrm{~h}$ at $60{ }^{\circ} \mathrm{C}$ and diluted to $3.5 \mathrm{~mL}$ with ultrapure water. This digestion protocol has previously given recoveries of $\mathrm{Cu}$ from $\mathrm{Cu}$ ENMs of $>90 \%$ (Shaw et al., 2012). Samples were compared to matrix matched analytical standards (Fisher, UK) that were also included throughout the run to correct for instrument drift. Procedural blanks $\left(\mathrm{HNO}_{3}\right.$ only) prepared at the same time and handled in the same manner as the samples were also included in the run to account for extraneous sources of $\mathrm{Cu}$. The limit of detection of the instrument run, calculated as the mean $+3 \times \mathrm{SD}$ of the $\mathrm{Cu}$ concentration in the procedural blanks was $0.21 \mu \mathrm{g} \mathrm{L}^{-1}$ and equated to $0.049 \mathrm{ng} \mathrm{Cu}$ larva $^{-1}$ in a digest contain- 
ing $n=15$ zebrafish. Concentrations of $\mathrm{Cu}$ in the animals are expressed as ng Cu larva ${ }^{-1}$ due to the low mass of the animals.

The activities of $\mathrm{Na}^{+} / \mathrm{K}^{+}$-ATPase and concentrations of total GSH in zebrafish were measured in microplates according to methods extensively detailed by Boyle et al. (2014) and following an original method for $\mathrm{Na}^{+} / \mathrm{K}^{+}$-ATPase activity by McCormick (1993). The larvae were homogenized in an ice-cold isotonic sucrose buffer (in mM: 300 sucrose, 20 HEPES, 0.1 EDTA. pH 7.8) using a hand-held motor-driven pestle. The homogenate was then centrifuged at $13000 \mathrm{rpm}$ for 2 min and the supernatant used in assays. Total glutathione was quantified in buffer with final assay concentrations of (in $\mathrm{mM}$ ): 76.5 phosphate buffer ( $\mathrm{pH}$ 7.5), 3.8 EDTA, 0.6 DNTB, 0.2 NADPH and $0.12 \mathrm{U} \mathrm{mL}^{-1}$ glutathione reductase. Activity of $\mathrm{Na}^{+} / \mathrm{K}^{+}$-ATPase was assayed with and without $0.5 \mathrm{mM}$ ouabain in buffer with final assay concentrations of (in $\mathrm{mM}$ ): 2.1 PEP, 0.53 ATP, 0.16 NADH, 37.25 HEPES, $47.25 \mathrm{NaCl}, 2.63 \mathrm{MgCl}_{2}$, $10.5 \mathrm{KCl}(\mathrm{pH} 7.5)$, and with $3.75 \mathrm{U} \mathrm{mL}^{-1}$ pyruvate kinase and $3 \mathrm{U} \mathrm{mL}^{-1}$ lactate dehydrogenase. Data were normalised to the total protein concentration in the supernatant measured with the Pierce BCA Protein Assay Kit according to the manufacturer's instructions (ThermoFisher Scientific, UK).

\subsection{Data handling and statistical analyses}

Probit analyses to calculate $\mathrm{LC}_{10}$ and $\mathrm{LC}_{50}$ (mortality) and $\mathrm{EC}_{50}$ (hatch) values for the materials were performed with SPSS (v. 22, SPSS Inc., US). Calculated $\mathrm{LC}_{50}$ and $\mathrm{EC}_{50}$ values are presented with 95\% confidence intervals (CI). All other statistical tests were performed with SigmaPlot (v. 13.0, Systat Software Inc.). Data are presented as means \pm standard error (SEM) except where stated. All data were tested for normality (Shapiro-Wilk test) and equality of variances (Brown-Forsythe test) and if not normally distributed were either $\log _{10}$ transformed or arcsine transformed. No observed effect concentrations and lowest observed effect concentrations for $\mathrm{Cu}\left(\right.$ as $\mathrm{CuSO}_{4}$ ) and $\mathrm{CuO}$ ENMs were calculated from acute toxicity data with one-way ANOVA. The data of ENM dissolution were fitted with a rectangular hyperbole function. Data of ENM settling were fitted with three-phase exponential decay curves. Statistically significant differences between datasets were detected using one-way and two-way ANOVA with the Holm-Sidak test a posteriori. A $p$ value of $<0.05$ was considered significant.

\section{Results}

\subsection{Physicochemical behaviours of CuO ENMs in suspension}

The $\mathrm{pH}$ of the media had little effect on the settling rates of the ENMs in beakers without animals present, but the ionic strength of the tap water media clearly did (Fig. 1B). In all media tested, $>50 \%$ of the ENMs were removed from suspension in $1 \mathrm{~h}$, and the measured total $\mathrm{Cu}$ concentrations in the beakers was stable between 6 and $24 \mathrm{~h}$. In Plymouth tap water adjusted to $\mathrm{pH} 5, \mathrm{pH} 6$ and $\mathrm{pH} 7$, total $\mathrm{Cu}$ concentrations in suspension at $24 \mathrm{~h}$ were $0.91 \pm 0.02,0.71 \pm 0.02,0.73 \pm 0.12 \mathrm{mg} \mathrm{Cu}$ $\mathrm{L}^{-1}$, respectively. This compared to $25.87 \pm 0.46 \mathrm{mg} \mathrm{Cu} \mathrm{L}^{-1}$ remaining in suspension in ultrapure water.

Despite the rapid loss of the ENMs from suspension (Fig. 1B), ENMs were still present in the suspensions at $24 \mathrm{~h}$ (Fig. 1C). There was also little difference in either particle number concentration or hydrodynamic diameters of the agglomerates in the tap water adjusted to different $\mathrm{pH}$ values. The total concentration of particulates at $24 \mathrm{~h}$ was $0.96 \pm 0.31,0.75 \pm 0.18$ and $1.48 \pm 0.64 \times 10^{8}$ particles $\mathrm{mL}^{-1}$, at $\mathrm{pH}$ 5 , pH 6 and $\mathrm{pH} 7$, respectively. This was a considerably lower than the $3.37 \pm 0.48 \times 10^{8}$ particles $\mathrm{mL}^{-1}$ in ultrapure water at $24 \mathrm{~h}$, but greater than the background concentration of particulates in Plymouth tap water, $0.22 \times 10^{8}$ particles $\mathrm{mL}^{-1}$. There was little difference in the hydrodynamic diameters of particles in suspension at $24 \mathrm{~h}$ in any media (Fig. $1 \mathrm{C}$ ). At all the $\mathrm{pH}$ values tested, and in ultrapure water,
$>50 \%$ of particles/agglomerates in suspension were $<90 \mathrm{~nm}$ and few larger agglomerates were in suspension.

The $\mathrm{pH}$ of Plymouth tap water had a pronounced effect on the rate and extent of dissolution of the CuO ENMs (Fig. 1D). As the $\mathrm{pH}$ of the water was decreased, the concentration of dissolved $\mathrm{Cu}$ in the beakers increased. The pattern of $\mathrm{Cu}$ release (ENM dissolution) over time was similar at all $\mathrm{pH}$ values and was characterised by an initial rapid release (greatest at $\mathrm{pH} \mathrm{5}$ ) in the first $1 \mathrm{~h}$, followed by a steady decrease in the rate of $\mathrm{Cu}$ release to a point of stable equilibrium in the closed volume system. During the first hour, rates of dissolution were $12.96 \pm 0.55$, $1.74 \pm 0.02$ and $0.50 \pm 0.01 \mu \mathrm{g} \mathrm{mg}^{-1} \mathrm{CuO} \mathrm{ENM} \mathrm{h}^{-1}$ at $\mathrm{pH} 5, \mathrm{pH} 6$ and $\mathrm{pH} 7$, respectively. After $24 \mathrm{~h}$, dissolved $\mathrm{Cu}$ concentrations in the external compartment of the beaker were: $6.27 \pm 0.11 \%, 0.75 \pm 0.10 \%$ and $0.21 \pm 0.03 \%$ of the initial total $\mathrm{Cu}$ added to the dialysis bags at $\mathrm{pH} 5$, 6 and 7, respectively. In comparison, $2.68 \pm 0.14 \%$ of total $\mathrm{Cu}$ as $\mathrm{CuO}$ ENMs was in the dissolved form after $24 \mathrm{~h}$ in ultrapure water.

\subsection{Acute toxicity and hatch inhibition of CuO ENMs}

The CuO ENMs were much less toxic to early life-stage zebrafish compared to $\mathrm{Cu}$ in the form of $\mathrm{CuSO}_{4}\left(96 \mathrm{~h} \mathrm{LC}_{50}\right.$ are shown in Fig. 2A, raw data are shown in Supplementary Fig. S2). At pH 7, 50\% mortality of zebrafish was not observed at concentrations of CuO ENMs of $\leq 100 \mathrm{mg} \mathrm{L}^{-1}$. This compared with a $\mathrm{LC}_{50}(95 \% \mathrm{CI})$ of $0.27(0.25-0.29)$ $\mathrm{mg} \mathrm{L}^{-1}$ for $\mathrm{Cu}$ as $\mathrm{CuSO}_{4}$. At acid $\mathrm{pH}$ the toxicities of both substances, and especially the CuO ENMs, were changed. The $\mathrm{LC}_{50}$ of the CuO ENMs decreased to 19.5 (11.6-27.2) $\mathrm{mg} \mathrm{L}^{-1}$ at $\mathrm{pH} 6$, and to 6.6 (4.5-8.5) $\mathrm{mg} \mathrm{L}^{-1}$ at $\mathrm{pH} 5$. In contrast, the toxicity of $\mathrm{CuSO}_{4}$ was more consistent across all $\mathrm{pH}$ tested, but was slightly less toxic at $\mathrm{pH} 5$ ( $\mathrm{LC}_{50} 0.36,95 \% \mathrm{CI}$ $0.33-0.40)$ than at $\mathrm{pH} 6\left(\mathrm{LC}_{50} 0.22,95 \% \mathrm{CI} 0.20-0.24\right)$ and $\mathrm{pH} 7$. The increase in acute toxicity of the $\mathrm{CuO}$ ENMs at acid $\mathrm{pH}$ also corresponded to the predicted increase in the dissolved fraction of $\mathrm{Cu}$ which would be in exposures to the $\mathrm{CuO}$ ENMs (i.e., the $\mathrm{Cu}$ release determined by dialysis, data shown in Fig. 1D). With the exception of $\mathrm{pH} 7$, the estimated concentrations of dissolved $\mathrm{Cu}$ in exposures to ENMs at the calculated $\mathrm{LC}_{50}$ values are shown as the hatched areas of the bars and show overlap with the calculated $\mathrm{LC}_{50}$ for $\mathrm{CuSO}_{4}$ (Fig. 2A).

Calculated NOECs and LOECs were dependent on concentrations used in the acute toxicity tests and are shown here for completeness. Calculated NOECs were 5 and $40 \mathrm{mg} \mathrm{L}^{-1} \mathrm{CuO}$ ENMs at $\mathrm{pH} 6$ and $\mathrm{pH}$ 7, respectively. A NOEC was not calculable at pH 5. LOECs for CuO ENMs were 1,10 and $50 \mathrm{mg} \mathrm{L}^{-1}$ at $\mathrm{pH} 5, \mathrm{pH} 6$ and $\mathrm{pH}$ 7, respectively. Calculated NOECs were $0.25,0.1,0.2 \mathrm{mg} \mathrm{L}^{-1} \mathrm{Cu}$ as $\mathrm{CuSO}_{4}$ at pH 5, pH 6 and $\mathrm{pH} 7$, respectively. Calculated LOECs were $0.3,0.15,0.25 \mathrm{mg} \mathrm{L}^{-1} \mathrm{Cu}$ as $\mathrm{CuSO}_{4}$ at pH 5, pH 6 and $\mathrm{pH}$ 7, respectively.

Inhibition of embryo hatching also occurred at lower concentrations in exposures to $\mathrm{CuSO}_{4}$ compared to CuO ENMs (Fig. 2B, Supplementary Fig. S2). For example, at $\mathrm{pH} 7$ calculated $\mathrm{EC}_{50}$ were 0.12 and $11.05 \mathrm{mg} \mathrm{L}^{-1}$ of $\mathrm{Cu}$ as $\mathrm{CuSO}_{4}$ and $\mathrm{CuO}$ ENMs, respectively. In exposures with $\mathrm{CuSO}_{4}$, there was also no indication of a $\mathrm{pH}$-dependent effect on hatch and $\mathrm{EC}_{50}$ values were similar at acid and neutral $\mathrm{pH}$. In contrast, there was a clear effect of the ENMs on hatch inhibition, greater effect at acid $\mathrm{pH}$, but there was no agreement between the estimated concentration of dissolved $\mathrm{Cu}$ in exposures to the CuO ENMs and hatch inhibition observed from $\mathrm{CuSO}_{4}$ exposure i.e. no overlap of the hatched area, with the exception of exposures at $\mathrm{pH} 5$.

\subsection{Effects of $\mathrm{CuSO}_{4}$ and $\mathrm{CuO}$ ENMs during low dose $\mathrm{LC}_{10}$ pulse exposure at $\mathrm{pH} 6$}

Investigation of the importance of pulse exposure to $\mathrm{CuO}$ ENMs or $\mathrm{CuSO}_{4}$ in acid waters was performed at $\mathrm{pH}$ 6. Low ( $\mathrm{LC}_{10}$ ) concentrations of both substances were calculated from the nominal concentra- 

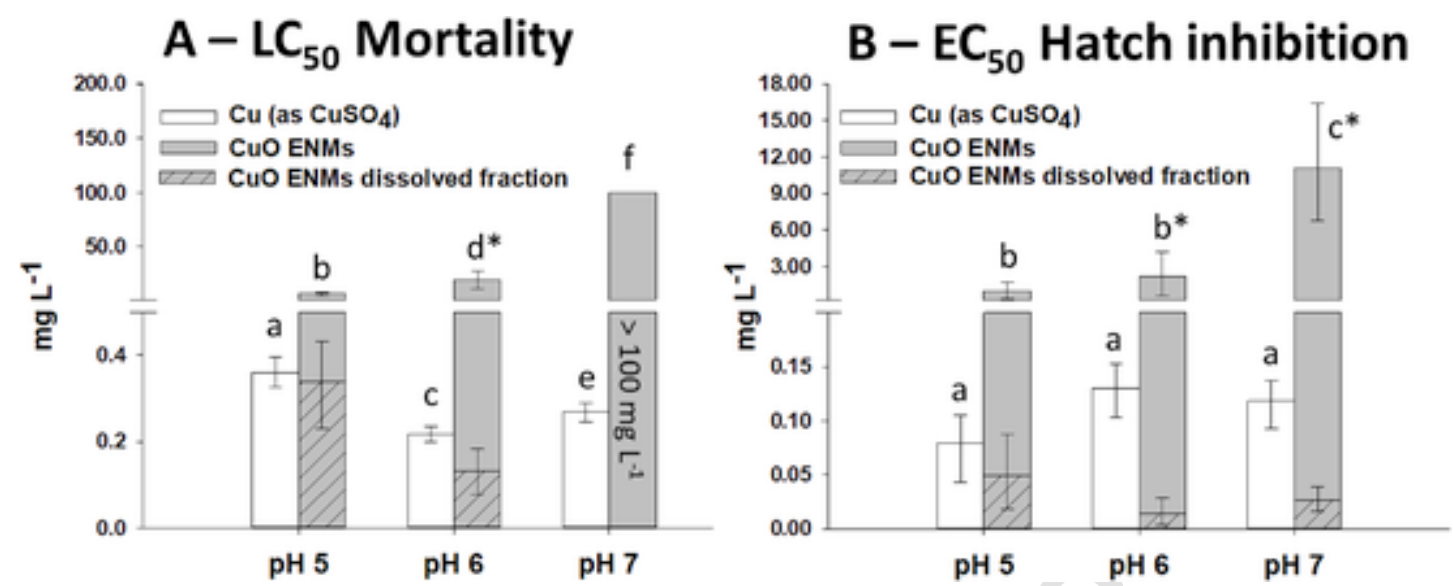

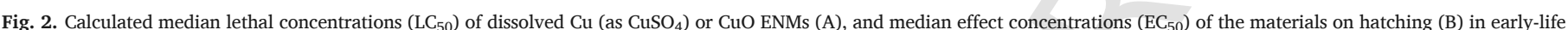

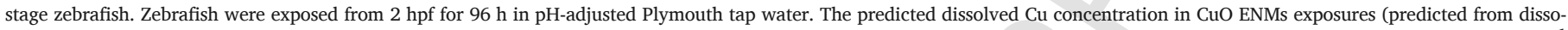

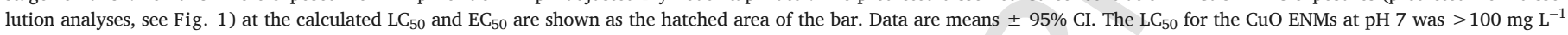

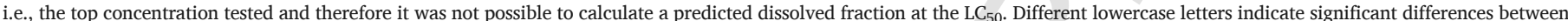

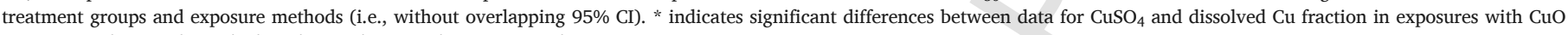
ENMs. Raw data used to calculate these values are shown in Supplementary Fig. S2.

tions used in the acute toxicity exposures (i.e., Supplementary Fig. S2) and were 6.54 and $0.151 \mathrm{mg} \mathrm{L}^{-1}$ for $\mathrm{CuO}$ ENMs and $\mathrm{Cu}$ as $\mathrm{CuSO}_{4}$, respectively. Measured total $\mathrm{Cu}$ concentrations in the vessels immediately after dosing were $3.83 \pm 0.22$ and $0.136 \pm 0.014 \mathrm{mg} \mathrm{L}^{-1}$ (means $\pm \mathrm{SD}, n=8$ ) for ENMs and $\mathrm{CuSO}_{4}$ treatments, respectively. Unlike the CuO ENMs (see Fig. 1B for settling rates) the concentration of $\mathrm{Cu}$ in solution in the $\mathrm{CuSO}_{4}$ treatment was stable during the period between media renewals and after $24 \mathrm{~h}, 90 \pm 3 \%$ of the initial $0 \mathrm{~h}$ concentration remained in solution. The $\mathrm{pH}$ of the water increased from $\mathrm{pH}$ 6.0 to $\mathrm{pH} 6.41 \pm 0.04$ ( $n=12$ beakers; there were no significant differences between treatments).

Mortalities were observed in zebrafish exposed to low concentrations of $\mathrm{CuSO}_{4}$ and $\mathrm{CuO}$ ENMs, and there was also a $12.1 \pm 4.7 \%$ incidence of background mortality in controls (Table 1). However, there were no significant differences in the percentage of mortalities between treatment groups or between treatment groups and the control (one-way ANOVA, $p=0.119$ ). Nevertheless, there were clear trends in the data to suggest greater mortality associated with exposure to the $\mathrm{Cu}$ materials. Hatching was significantly inhibited by exposure to the $\mathrm{Cu}$ substances at $\mathrm{LC}_{10}$ and this was expected (see section 3.2, one-

Table 1

Mortality and hatch of zebrafish at $96 \mathrm{hpf}$ after exposure to $\mathrm{CuSO}_{4}$ or $\mathrm{CuO}$ ENMs at $\mathrm{LC}_{10}$.

\begin{tabular}{|c|c|c|c|}
\hline Substance & Exposure & Mortality (\%) & Hatch (\%) ${ }^{a}$ \\
\hline - & Control & $12.1 \pm 4.7^{\mathrm{a}}$ & $98.6 \pm 0.5^{\mathrm{a}}$ \\
\hline \multirow[t]{3}{*}{$\mathrm{CuSO}_{4}$} & $\begin{array}{l}\text { Early } \\
0-24 \mathrm{~h}\end{array}$ & $17.1 \pm 1.7^{\mathrm{a}}$ & $39.2 \pm 4.8^{b}$ \\
\hline & $\begin{array}{l}\text { Pulse } \\
24-48 \\
72-96 \text { h }\end{array}$ & $27.9 \pm 8.5^{a}$ & $8.4 \pm 1.0^{c}$ \\
\hline & $\begin{array}{l}\text { Continuous } \\
0-96 \mathrm{~h}\end{array}$ & $47.9 \pm 14.6^{a}$ & $0^{c}$ \\
\hline \multirow[t]{3}{*}{ CuO ENMs } & $\begin{array}{l}\text { Early } \\
0-24 \text { h }\end{array}$ & $46.7 \pm 8.8^{a}$ & $11.3 \pm 2.0^{c}$ \\
\hline & $\begin{array}{l}\text { Pulse } \\
24-48, \\
72-96 \text { h }\end{array}$ & $34.2 \pm 11.7^{\mathrm{a}}$ & $4.5 \pm 2.7^{c}$ \\
\hline & $\begin{array}{l}\text { Continuous } \\
0-96 \mathrm{~h}\end{array}$ & $39.2 \pm 13.0^{\mathrm{a}}$ & $4.2 \pm 0.9^{c}$ \\
\hline
\end{tabular}

Data are means \pm SEM $(n=4)$.

Different lower case letters indicate significant differences between treatments (one-way ANOVA, Holm-Sidak post hoc test, $p<0.05$ ).

a Hatch is expressed as the percentage of the surviving zebrafish at $96 \mathrm{~h}$. way ANOVA, $p<0.001)$. Hatch was $98.6 \pm 0.5 \%$ of surviving control zebrafish at $96 \mathrm{hpf}$ but was significantly decreased after early, pulse and continuous exposures to both $\mathrm{Cu}$ materials. There were few significant differences between $\mathrm{Cu}$ treatments and exposures with one exception: early (0-24 hpf) exposure to $\mathrm{CuSO}_{4}$ had a lesser impact on hatch compared to early exposure to CuO ENMs, and all other treatment/exposure regimen.

The exposure was verified by measuring $\mathrm{Cu}$ concentrations in the embryos at $96 \mathrm{~h}$. Continuous exposure to $\mathrm{CuSO}_{4}$ or $\mathrm{CuO}$ ENMs for $96 \mathrm{~h}$ led to significant increases in $\mathrm{Cu}$ concentrations versus controls, only, in dechorionated embryos (one-way ANOVA, $p=0.002$, Holm-Sidak test for both materials $p<0.05$; Fig. 3 ). Neither early single pulse nor double pulse exposures led to measurable $\mathrm{Cu}$ increases compared to controls (all $p>0.05$ ). For chorionated embryos, Cu concentrations were much greater than for dechorionated zebrafish i.e., tissue associated $\mathrm{Cu}$ at $96 \mathrm{~h}$ (Fig. 3B). There was also significantly greater total $\mathrm{Cu}$ from $\mathrm{CuO}$ ENMs associated with the chorion compared to that for the $\mathrm{CuSO}_{4}$ treatment at their respective $\mathrm{LC}_{10}$ values (one-way ANOVA, $p<0.001$ ). For example, measured $\mathrm{Cu}$ concentrations in chorionated embryos from continuous exposures were $20 \pm 4$ and $1706 \pm 310 \mathrm{ng}$ larva $^{-1}$ from exposure to $\mathrm{CuSO}_{4}$ and CuO ENMs, respectively (Holm-Sidak test, $p<0.001$ ). It was not possible to measure $\mathrm{Cu}$ concentrations in chorionated control embryos because they had all hatched by $96 \mathrm{~h}$, with the exception of one animal.

At the $\mathrm{LC}_{10}$ concentrations used, both $\mathrm{CuSO}_{4}$ and $\mathrm{CuO}$ ENMs caused significant depletion of total GSH of approximately 50\% compared to control embryos after continuous exposure for $96 \mathrm{~h}$ (one-way ANOVA with Holm-Sidak test, both $p<0.001$ ). Moreover, there was no significant difference between the $\mathrm{Cu}$ forms (Holm-Sidak test, $p=0.178$ ). Within each substance, the magnitude of the depletion compared to controls was also the same irrespective of whether zebrafish embryos were exposed to two pulses of either CuO ENMs or $\mathrm{CuSO}_{4}$ or in continuous exposures (all Holm-Sidak post hoc test $p>0.05$ ). This was despite the double pulse exposed fish receiving half the total $\mathrm{Cu}$ dose as in the continuous exposures. Early single pulse exposure to both $\mathrm{Cu}$ materials for the first $24 \mathrm{~h}$ of development also resulted in significant depletion of GSH versus controls (both $p<0.001$ ) and there was evidence of a nanoscale specific effect with early exposure to $\mathrm{CuO}$ ENMs causing a significantly greater GSH depletion after $96 \mathrm{~h}$ as compared to $\mathrm{CuSO}_{4}$ ( $p=0.007)$.

The effects of $\mathrm{CuO}$ ENMs and $\mathrm{CuSO}_{4}$ on the activity of $\mathrm{Na}^{+} / \mathrm{K}^{+}$-ATPase mirrored the decreases in measured concentrations of total 
A

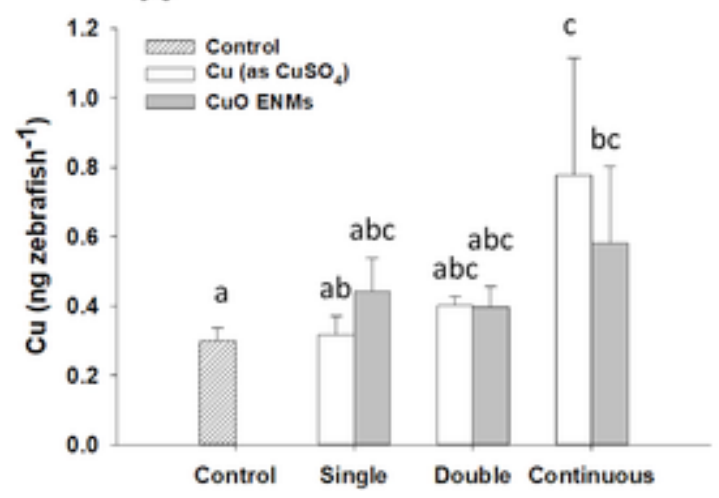

B

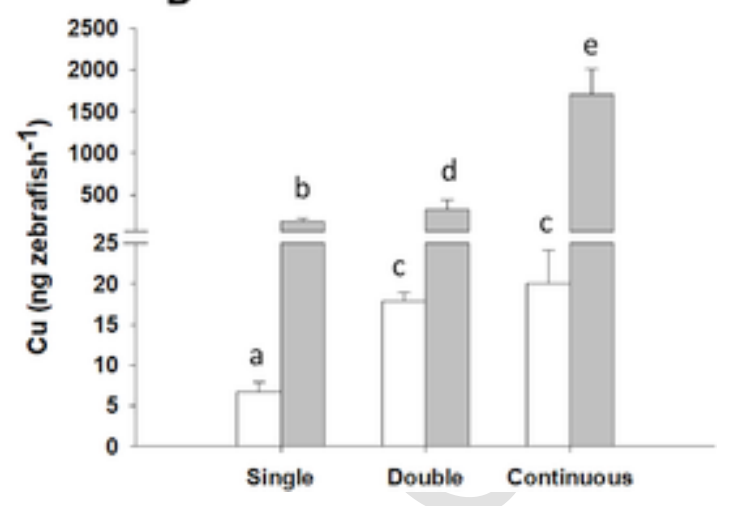

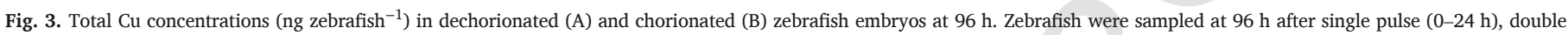

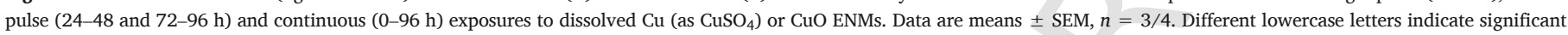
differences between treatment groups and exposure methods (one-way ANOVA, $p<0.05$ ). Note the differences in scale between panels (A) and (B).

GSH (one-way ANOVA, $p<0.001$ ). Continuous exposures to either $\mathrm{CuO}$ ENMs or $\mathrm{CuSO}_{4}$ caused inhibition of $\mathrm{Na}^{+} / \mathrm{K}^{+}$-ATPase compared to controls after $96 \mathrm{~h}$ (both Holm-Sidak, $\mathrm{p}<0.001$ ) with no significant differences between the substances ( $p=0.169$ ). Double pulse exposure also caused the same level of effect seen in embryos exposed continuously for $96 \mathrm{~h}$ (for comparisons within substances, $p>0.05$ ). There was also a significant nanomaterial effect from early single pulse $\mathrm{Cu}$ exposure with greater $\mathrm{Na}^{+} / \mathrm{K}^{+}$-ATPase inhibition in embryos observed for CuO ENMs as compared to $\mathrm{CuSO}_{4}(p=0.01)$.

\section{Discussion}

In this study, the data showed that the toxicity of CuO ENMs to zebrafish was much lower than that of $\mathrm{CuSO}_{4}$ at $\mathrm{pH} 7$, and as expected $\mathrm{CuSO}_{4}$ was also less toxic at $\mathrm{pH} 5$ than at $\mathrm{pH}$ 7. In contrast, CuO ENMs were more hazardous at lower $\mathrm{pH}$. In continuous $96 \mathrm{~h}$ exposures to the substances at $\mathrm{pH} 6$, both $\mathrm{CuSO}_{4}$ and $\mathrm{CuO}$ ENMs caused inhibition of $\mathrm{Na}^{+} / \mathrm{K}^{+}$-ATPase and depletions in total GSH in zebrafish. However, two $24 \mathrm{~h}$ pulses of $\mathrm{CuSO}_{4}$ or $\mathrm{CuO}$ ENMs caused the same magnitudes of effect on $\mathrm{Na}^{+} / \mathrm{K}^{+}$-ATPase and total GSH, suggesting on an equivalent dose basis that the latter is more hazardous.

\subsection{Toxicity of $\mathrm{CuSO}_{4}$ and $\mathrm{CuO}$ ENMs at low $\mathrm{pH}$}

At pH 7, the CuO ENMs were considerably less toxic than the $\mathrm{CuSO}_{4}$ (Fig. 2), with the median acute lethal toxicity concentration $\left(\mathrm{LC}_{50}\right)$ of CuO ENMs exceeding $100 \mathrm{mg} \mathrm{L}^{-1}$ which was above the highest concentration used in this experiment and a greater material concentration than is routinely used in regulatory toxicity tests (e.g., OECD TG 210). These data are in agreement with several other studies with different $\mathrm{Cu}$ ENMs in fish that have shown lower toxicity compared to dissolved $\mathrm{Cu}$ at neutral $\mathrm{pH}$ (Lin et al., 2013; Shaw et al., 2012; Vicario-Parés et al., 2014). At pH 5, the toxicity of $\mathrm{CuSO}_{4}$ was lower than at $\mathrm{pH} 7$ (Fig. 2) and the expected protective effect of low $\mathrm{pH}$ (Cusimano et al., 1986) is explained by competition between dissolved $\mathrm{Cu}$ and $\mathrm{H}^{+}$ for binding at the gills leading to reduced $\mathrm{Cu}$ uptake (Santore et al., 2001).

In contrast to $\mathrm{CuSO}_{4}$, the $\mathrm{CuO}$ ENMs showed increased toxicity at lower pH (Fig. 2) and this effect was almost entirely due to dissolution of dissolved $\mathrm{Cu}$ from the particles at low $\mathrm{pH}$ rather than any $\mathrm{pH}$-dependent effects on the particle dispersion. The CuO ENMs used here had moderate stability in ultrapure water (Fig. 1B) likely due to some charge repulsion (zeta potential of $+28.1 \mathrm{mV}$, Bicho et al. (2017)); but, in Plymouth tap water, the higher ionic strength of the media caused more particle settling than observed in ultrapure water (Fig. 1B). Peng et al. (2017) reported a pH of zero point of charge of 6.21 for uncoated $\mathrm{CuO}$ ENMs in $10 \mathrm{mM} \mathrm{NaCl}$ and with smaller agglomer- ates and greater suspension stability at pH 5 or lower. A similar pH-dependent effect of Plymouth tap water on suspension stability was not evident in the present study because the $\mathrm{pH}$ range tested was necessarily narrower here to avoid detrimental effects of $\mathrm{H}^{+}$toxicity to the zebrafish. However, lowering the water $\mathrm{pH}$ to 5 during dialysis experiments did increase the concentration of total $\mathrm{Cu}$ in suspension after $24 \mathrm{~h}$ when compared to $\mathrm{pH} 6$ and 7 and this was almost certainly due to greater ENM dissolution observed for acid water, as observed previously with Cu-containing particles (Al-Bairuty et al., 2016). Under acidic conditions, the high $\left[\mathrm{H}^{+}\right]$reacts with the CuO ENM surface to liberate $\mathrm{Cu}^{2+}$ (Wang et al., 2013). There was negligible mortality in the presence of acid $\mathrm{pH}$ alone (Fig. S3). It is therefore the $\mathrm{pH}$-dependent release of dissolved $\mathrm{Cu}$ from the CuO ENMs that is of most concern with respect to toxicity to the fish. The predicted dissolved $\mathrm{Cu}$ concentration from the dialysis experiments are close to the $\mathrm{LC}_{50}$ values for $\mathrm{CuSO}_{4}$ at pH 5 and pH 6 (Fig. 2A); suggesting that the dissolution of dissolved $\mathrm{Cu}$ from the particles best explains the observed mortality. The mortality was not confounded by the effects of $\mathrm{pH}$ alone on zebrafish biochemistry (no inhibition at those $\mathrm{pH}$ values, Fig. S3). The predominant role of dissolved $\mathrm{Cu}$ in the toxicity of $\mathrm{CuO}$ ENMs has also been documented in fish cell lines (e.g., Galbis-Martinez et al., 2018). In contrast, where $\mathrm{CuO}$ ENMs have been engineered to not dissolve in media (e.g., by Fe-doping the ENMs), the toxicity to zebrafish embryos has been ameliorated (Naatz et al., 2017).

Exposure to $\mathrm{CuSO}_{4}$ prevented the hatching success of the embryos, with a total $\mathrm{Cu}$ concentration of $0.4 \mathrm{mg} \mathrm{L}^{-1}$ or more causing $100 \%$ inhibition of hatching (Fig. S2), regardless of water $\mathrm{pH}$. The low $\mathrm{pH}$ alone caused negligible interference with hatching success (Fig. S2), suggesting the effect was mainly attributed to $\mathrm{CuSO}_{4}$ exposure. Hatching success was a sensitive endpoint for the metal salt with $\mathrm{EC}_{50}$ values of between 0.08 and $0.13 \mathrm{mg} \mathrm{L}^{-1}$ for $\mathrm{CuSO}_{4}$, and similar to previous reports on zebrafish $\left(52 \%\right.$ hatching success at $0.06 \mathrm{mg} \mathrm{L}^{-1}$ of $\mathrm{Cu}$ as $\mathrm{CuSO}_{4}$, Bai et al., 2010). The CuO ENMs also inhibited hatching success, but only at concentrations an order of magnitude higher than that of the equivalent $\mathrm{CuSO}_{4}$ treatment (Fig. 2B). Notably, only a small fraction of the $\mathrm{EC}_{50}$ for hatching could be attributed to the estimated dissolved $\mathrm{Cu}$ concentration arising from particle dissolution, especially at pH 6 and 7 (Fig. 2B), suggesting mechanisms other than dissolved $\mathrm{Cu}$ toxicity. Failure of zebrafish hatching has been shown for several ENMs, including CuO (e.g., Bai et al., 2010; Lin et al., 2013; Ong et al., 2014b; Muller et al., 2015). However, the mechanisms involved are disputed. Increased locomotor activity, combined with a weakening of the chorion via a protease enzyme secreted into the perivitelline fluid, usually enables hatching success. In the presence of ENMs, inhibition of the protease activity needed for hatch (assumed zebrafish hatching enzyme, Zhe1) has been demonstrated (Ong et al., 2014b). How- 
ever, oxidative stress from CuO ENM exposure may preferentially reduce locomotor activity of the embryo so that the animal cannot break through the chorion, rather than altering the gene expression controlling the secretion of the protease (Zhang et al., 2018). The precise mechanism by which oxidative stress from CuO ENMs reduces motility in the embryo is less clear, but for example, could involve damage to the skeletal muscle fibres on the flank of this fish (observed in trout, Al-Bairuty et al., 2013) or respiratory distress (i.e., inability to exercise).

\subsection{Effects of pulse exposures}

The pulse exposures caused low levels of mortality, as expected for the $\mathrm{LC}_{10}$ concentrations of each form of $\mathrm{Cu}$ used, but sub-lethal effects were able to be measured in a majority of the animals. The focus was therefore on $\mathrm{Cu}$ accumulation and sub-lethal effects in the animals relative to the exposure dose in the pulses compared to the continuous exposure. The unhatched animals (i.e., not dechorionated) from the $\mathrm{CuSO}_{4}$ treatment showed more apparent $\mathrm{Cu}$ accumulation in/on the embryos in the double pulse compared to the single pulse, in keeping with the dosimetry. This was not the case for the continuous exposure which was not different from the double pulse of $\mathrm{CuSO}_{4}$ (Fig. 3B). However, the $\mathrm{Cu}$ concentrations in the unhatched animals should be interpreted with caution, because the dechorionated animals had orders of magnitude less total $\mathrm{Cu}$ (Fig. 3A) and this strongly suggests that most of the $\mathrm{Cu}$ was surface-bound. The binding of divalent cations to polyanionic residues (Shephard, 1989), such as those in the chorion and the mucoproteins in the perivitelline fluid is well-known and this severely limits the diffusion of soluble divalent metals to protect the embryo inside the egg (Peterson and Martin-Robichaud, 1986). In the dechorionated animals, the total $\mathrm{Cu}$ concentrations in the $\mathrm{CuSO}_{4}$ treatment were not any different from the controls, except in the continuous exposure (Fig. 3A).

Despite the limited internal accumulation of $\mathrm{Cu}$ in the embryos, there were some depletions of total GSH and inhibition of the $\mathrm{Na}^{+} / \mathrm{K}^{+}$-ATPase activity in the $\mathrm{CuSO}_{4}$ treatments compared to the unexposed controls (Fig. 4). This observation is consistent with the mechanisms of dissolved $\mathrm{Cu}$ toxicity to fish i.e. oxidative stress and ionoregulatory disturbances (Grosell, 2012; Handy, 2003). Glutathione is the first line of defence against oxidative stress in fish and is also a $\mathrm{Cu}$ chaperone (Handy, 2003). The modest decrease in total GSH here (i.e., not depleted, Fig. 4) has also been seen in trout (e.g., Shaw et al., 2012), and in such circumstances there is no evidence of gross pathology due to oxidative damage in vivo (Al-Bairuty et al., 2013). Regardless of the mechanistic details, the double pulse caused more depletion of total GSH and inhibition of $\mathrm{Na}^{+} / \mathrm{K}^{+}$-ATPase activity than the single pulse

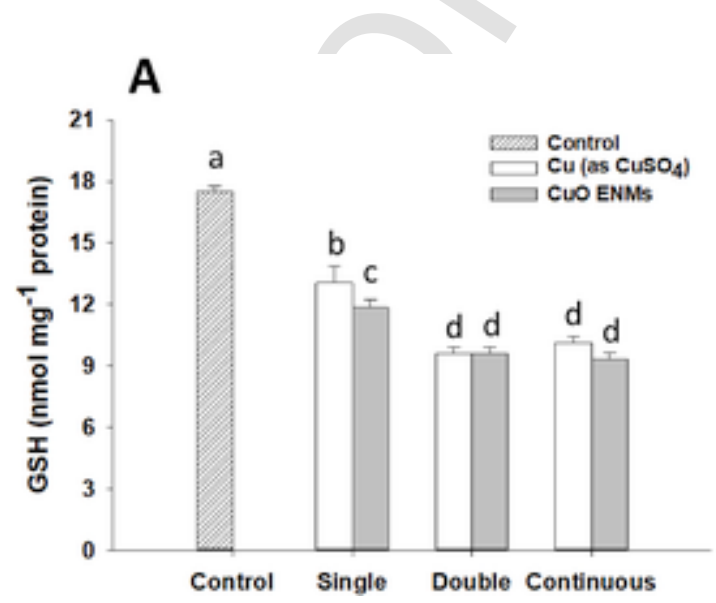

of $\mathrm{CuSO}_{4}$, suggesting that multiple pulses may be more hazardous, as shown previously for metals (Handy, 1994), partly because the double pulse inevitably has double the exposure dose. Notably, the double pulse had the same effect on total GSH and $\mathrm{Na}^{+} / \mathrm{K}^{+}$-ATPase activity as the continuous exposure. Since the peak concentrations in the pulse and continuous exposures were similar, then the notion that the 'dose' equals concentration multiplied by exposure time can be applied (Handy, 1994). The two $24 \mathrm{~h}$ pulses had the same net effect on biochemistry, at half the dose of the continuous exposure, therefore the double pulse can be regarded as more hazardous. Nevertheless, the biochemistry (Fig. 4) did not correlate well with the accumulated Cu concentration in the individual animals from the pulses, suggesting other secondary effects of $\mathrm{CuSO}_{4}$ exposure were responsible for the biochemical perturbations. For example, sodium ion depletion from the embryo (Alsop and Wood, 2011) leading to inhibition of $\mathrm{Na}^{+} / \mathrm{K}^{+}$-ATPase activity.

The pattern of $\mathrm{Cu}$ accumulation and sub-lethal effects in the animals following pulse exposures to CuO ENMs broadly followed that of $\mathrm{CuSO}_{4}$ with two important exceptions. Firstly, the relative $\mathrm{Cu}$ accumulation in the intact animals with a chorion (i.e., mostly surface adsorption to the chorion) was higher than that of the equivalent $\mathrm{CuSO}_{4}$ treatment (Fig. 3B). The attachment of CuO ENMs to the chorion of zebrafish embryos has been demonstrated by microscopy (Böhme et al., 2017). Copper oxide ENMs have also recently been shown not to accumulate in adult zebrafish (Vicario-Parés et al., 2018). Secondly, the present study also showed greater sub-lethal effects of early exposure to $\mathrm{CuO}$ ENMs than $\mathrm{CuSO}_{4}$. This implies that while the CuO ENM had low bioavailability compared to the metal salt, it may present a greater hazard to fish embryos when delivered as a pulse. Indeed, the single pulse of $\mathrm{CuO}$ ENMs caused more depletion of total GSH and inhibition of the $\mathrm{Na}^{+} / \mathrm{K}^{+}$-ATPase activity than the equivalent pulse of $\mathrm{CuSO}_{4}$ after $96 \mathrm{~h}$ (Fig. 4). The depletion of total GSH in conjunction with decreased activity of $\mathrm{Na}^{+} / \mathrm{K}^{+}$-ATPase, might suggest a loss of antioxidant capacity, or rather some oxidative injury to the protein structure of the enzyme, was partly driving failure of the $\mathrm{Na}^{+}$pump. A broadly similar observation was made on toxicity in Daphnia magna in which greater toxicity in pulse exposure to $\mathrm{CuO}$ ENMs than dissolved $\mathrm{Cu}$ was attributed to higher retention of ENMs in the gut (Sørensen et al., 2016).

\subsection{Conclusions and regulatory perspective}

The CuO ENMs were acutely toxic to zebrafish embryos and dissolution of dissolved $\mathrm{Cu}$ from the particles was a key factor in the particle toxicity. Overall, the $\mathrm{CuO}$ ENMs were less toxic than $\mathrm{CuSO}_{4}$, but crucially and unlike the metal salt, the nano form became more haz-

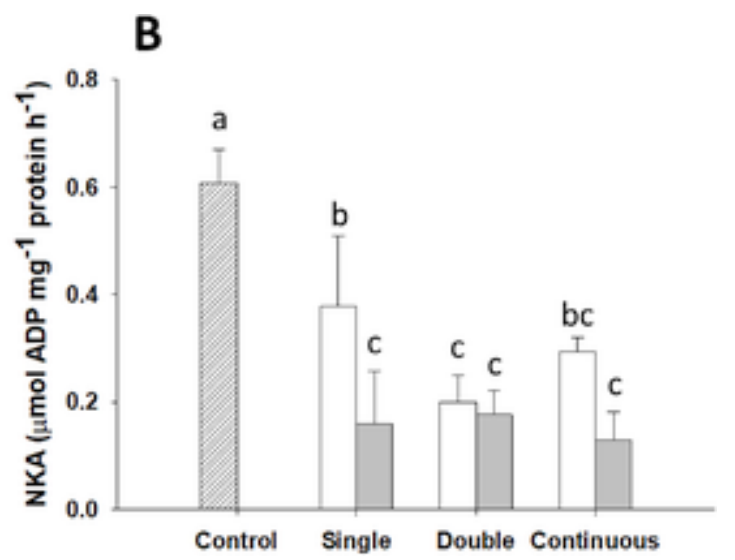

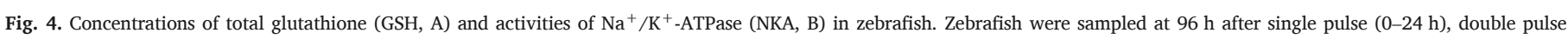

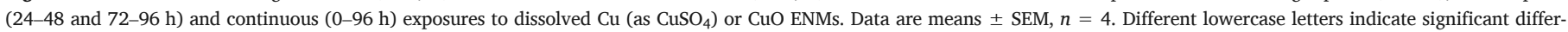
ences between treatment groups and exposure methods (one-way ANOVA, $p<0.05$ ). 
ardous at low $\mathrm{pH}$. In the pulse exposure studies at $\mathrm{pH}$ 6, the embryos exposed continuously to either $\mathrm{CuSO}_{4}$ or $\mathrm{CuO}$ ENMs showed a trend toward more $\mathrm{Cu}$ accumulation than either of the pulse exposures, in keeping with the exposure dose informing on total $\mathrm{Cu}$ accumulation. However, there were sub-lethal toxic effects associated with the pulses that were more likely explained by secondary oxidative stress than as a consequence of the total $\mathrm{Cu}$ concentration inside the animals. Importantly, the double pulse was as toxic as the continuous exposure, suggesting that repeated intermittent exposure to $\mathrm{CuO}$ ENMs present an additional hazard that would not be detected in routine continuous exposure test methods with zebrafish. From a regulatory perspective and the application of models such as the BLM (Santore et al., 2001), the assumption that $\mathrm{H}^{+}$is protective of metal toxicity may not apply to ENMs. Thus current catchment specific corrections of water quality criteria for $\mathrm{pH}$ will not protect from $\mathrm{Cu}$ toxicity in the nano form. The demonstration that pulses of ENMs might be as toxic as a continuous exposure should also be considered with respect to permits for consented discharges. More understanding of the temporal profiles of ENMs in natural water is also needed to inform the risk assessment.

\section{Author contribution statement}

Boyle: Conceptualisation, methodology, validation, formal analysis, investigation, data curation, writing - original draft and editing, visualisation, data curation, project administration. Clark: validation, formal analysis, investigation, writing - contribution to original draft. Handy: Conceptualisation, methodology, data curation, writing - original draft, review and editing, supervision, project administration, funding acquisition.

\section{Declaration of competing interests}

The authors have no interests to declare.

\section{Acknowledgements}

This research was supported by the Sustainable Nanotechnologies Project (SUN) grant, contract number 604305 funded under the EU FP7 research programme. RDH was the PI at Plymouth University. The authors thank Andrew Atfield for technical support in biology, Andrew Fisher and Robert Clough for support on trace metal analysis, and Peter Bond for technical assistance in the Plymouth Electron Microscopy Centre.

\section{Appendix A. Supplementary data}

Supplementary data to this article can be found online at https://doi. org/10.1016/j.ecoenv.2019.109985.

\section{Uncited references}

Fromm, 1980, Kwong et al., 2014.

\section{References}

Al-Bairuty, G.A., Shaw, B.J., Handy, R.D., Henry, T.B., 2013. Histopathological effects of waterborne copper nanoparticles and copper sulphate on the organs of rainbow trout (Oncorhynchus mykiss). Aquat. Toxicol. 126, 104-115.

Al-Bairuty, G.A., Boyle, D., Henry, T.B., Handy, R.D., 2016. Sublethal effects of copper sulphate compared to copper nanoparticles in rainbow trout (Oncorhynchus mykiss) at low pH: physiology and metal accumulation. Aquat. Toxicol. 174, 188-198.

Alexander, A.C., Chambers, P.A., Jeffries, D.S., 2017. Episodic acidification of 5 rivers in Canada's oil sands during snowmelt: a 25-year record. Sci. Total Environ. 599, 739-749.

Alsop, D., Wood, C.M., 2011. Metal uptake and acute toxicity in zebrafish: common mechanisms across multiple metals. Aquat. Toxicol. 105, 385-393.

Artigas, J., Arts, G., Babut, M., Caracciolo, A.B., Charles, S., Chaumot, A., Combourieu, B., Dahllöf, I., Despréaux, D., Ferrari, B., Friberg, N., Garric, J., Geffard, O., Gourlay-Francé, C., Hein, M., Hjorth, M., Krauss, M., De Lange, H.J., Lahr, J., Lehtonen, K.K.
, Lettieri, T., Liess, M., Lofts, S., Mayer, P., Morin, S., Paschke, A., Svendsen, C., Usseglio-Polatera, P., van den Brink, N., Vindimian, E., Williams, R., 2012. Towards a renewed research agenda in ecotoxicology. Environ. Pollut. 160, 201-206.

Bai, W., Tian, W., Zhang, Z., He, X., Ma, Y., Liu, N., Chai, Z., 2010. Effects of copper nanoparticles on the development of zebrafish embryos. J. Nanosci. Nanotechnol. 10, 8670-8676.

Bearr, J.S., Diamond, J., Latimer, H., Bowersox, M., 2006. Effects of pulsed copper exposures on early life-stage Pimephales promelas. Environ. Toxicol. Chem. 25, 1376-1382.

Bicho, R.C., Santos, F.C.F., Scott-Fordsmand, J.J., Amorim, M.J.B., 2017. Effects of copper oxide nanomaterials (CuONMs) are life stage dependent - full life cycle in Enchytraeus crypticus. Environ. Pollut. 224, 117-124.

Boyle, D., Fox, J.E., Akerman, J.M., Sloman, K.A., Henry, T.B., Handy, R.D., 2014. Minimal effects of waterborne exposure to single-walled carbon nanotubes on behaviour and physiology of juvenile rainbow trout (Oncorhynchus mykiss). Aquat. Toxicol. 146, 154-164.

Böhme, S., Baccaro, M., Schmidt, M., Potthoff, A., Stärk, H.J., Reemtsma, T., Kühnel, D., 2017. Metal uptake and distribution in the zebrafish (Danio rerio) embryo: differences between nanoparticles and metal ions. Environ. Sci.: Nano 5, 1005-1015.

Cairns, J., 1983. Are single species toxicity tests alone adequate for estimating environmental hazard? Hydrobiologia 100, 47-57.

Crane, M., Handy, R.D., Garrod, J., Owen, R., 2008. Ecotoxicity test methods and environmental hazard assessment for manufactured nanoparticles. Ecotoxicology 17, 421-437.

Cusimano, R.F., Brakke, D.F., Chapman, G.A., 1986. Effects of pH on the toxicities of cadmium, copper, and zinc to steelhead trout (Salmo gairdneri). Can. J. Fish. Aquat. Sci. 43, 1497-1503.

Dold, B., 2014. Evolution of acid mine drainage formation in sulphidic mine tailings. Minerals 4, 621-641.

Edwards, D.D., Moore, P.A., 2014. Real exposure: field measurement of chemical plumes in headwater streams. Arch. Environ. Contam. Toxicol. 67, 413-425.

Freda, J., McDonald, D.G., 1988. Physiological correlates of interspecific variation in acid tolerance in fish. J. Exp. Biol. 136, 243-258.

Fromm, P.O., 1980. A review of some physiological and toxicological responses of freshwater fish to acid stress. Environ. Biol. Fish. 5, 79-93.

Galbis-Martinez, L., Fernandez-Cruz, M.L., Alte, L., Valdehita, A., Rucandio, I., Navas, J.M., 2018. Development of a new tool for the long term in vitro ecotoxicity testing of nanomaterials using a rainbow-trout cell line (RTL-W1). Toxicol. In Vitro 50, 305-317.

Griffitt, R.J., Weil, R., Hyndman, K.A., Denslow, N.D., Powers, K., Taylor, D., Barber, D.S., 2007. Exposure to copper nanoparticles causes gill injury and acute lethality in zebrafish (Danio rerio). Environ. Sci. Technol. 41, 8178-8186.

Grosell, M., McGeer, J.C., Wood, C.M., 2001. Plasma copper clearance and biliary copper excretion are stimulated in copper-acclimated trout. Am. J. Physiol. 280, R796-R806.

Grosell, M., 2012. Copper. In: Wood, C.M., Farrell, A.P., Brauner, C.J. (Eds.), Homeostasis and Toxicology of Essential Metals. Elsevier Inc., London, pp. 53-133.

Handy, R.D., Eddy, F.B., Romain, G., 1989. In vitro evidence for the ionoregulatory role of rainbow trout mucus in acid, acid/aluminium and zinc toxicity. J. Fish Biol. 35, 737-747.

Handy, R.D., 1992. The assessment of episodic metal pollution. 1. Uses and limitations of tissue contaminant analysis in rainbow trout (Oncorhynchus mykiss) after short waterborne exposure to cadmium or copper. Arch. Environ. Contam. Toxicol. 22, 74-81.

Handy, R.D., 1994. Intermittent exposure to aquatic pollutants: assessment, toxicity and sublethal responses in fish and invertebrates. Comp. Biochem. Physiol., C 107, 171-184.

Handy, R.D., 2003. Chronic effects of copper exposure versus endocrine toxicity: two sides of the same toxicological process? Comp. Biochem. Physiol. A 135, 25-38.

Handy, R.D., van den Brink, N., Chappell, M., Mühling, M., Behra, R., Dušinská, M., Simpson, P., Ahtiainen, J., Jha, A.N., Seiter, J., Bednar, A., Kennedy, A., Fernandes, T.F., Riediker, M., 2012. Practical considerations for conducting ecotoxicity test methods with manufactured nanomaterials: what have we learnt so far? Ecotoxicology 21, 933-972.

Hindar, A., Nordstrom, D.K., 2015. Effects and quantification of acid runoff from sulfide-bearing rock deposited during construction of highway E18, Norway. Appl. Geochem. 62, 150-163.

Horng, J.-L., Lin, L.-Y., Hwang, P.-P., 2009. Functional regulation of $\mathrm{H}^{+}$-ATPase-rich cells in zebrafish embryos acclimated to an acidic environment. Am. J. Physiol. 296, C682-C692.

Kwong, R.W.M., Perry, S.F., 2013. The tight junction protein claudin-b regulates epithelial permeability and sodium handling in larval zebrafish, Danio rerio. Am. J. Physiol. 304, R504-R513.

Kwong, R.W.M., Kumai, Y., Perry, S.F., 2014. The physiology of fish at low pH: the zebrafish as a model system. J. Exp. Biol. 217, 651-662.

Laurén, D.J., McDonald, D.G., 1985. Effects of copper on branchial ionoregulation in the rainbow trout, Salmo gairdneri Richardson. J. Comp. Physiol. 155B, 635-644.

Lewis, L., Kwong, R.W.M., 2018. Zebrafish as a model system for investigating the compensatory regulation of ionic balance during metabolic acidosis. Int. J. Mol. Sci. 19, 1087. doi:10.3390/ijms19041087.

Lin, S., Zhao, Y., Xia, T., Meng, H., Ji, Z., Liu, R., George, S., Xiong, S., Wang, X., Zhang, H., Pokhrel, S., Mädler, L., Damoiseaux, R., Lin, S., Nel, A.E., 2013. High content screening in zebrafish speeds up hazard ranking of transition metal oxide nanoparticles. ACS Nano 5, 7284-7295.

McCahon, C.P., Pascoe, D., 1990. Episodic pollution: causes, toxicological effects and ecological significance. Funct. Ecol. 4, 375-383.

McCarty, L.S., Borgert, C.J., Posthuma, L., 2018. The regulatory challenge of chemicals in the environment: toxicity testing, risk assessment, and decision-making models. Regul. Toxicol. Pharmacol. 99, 289-295.

McCormick, S.D., 1993. Methods for non-lethal gill biopsy and measurement of $\mathrm{Na}^{+}$, $\mathrm{K}^{+}$-ATPase activity. Can. J. Fish. Aquat. Sci. 50, 656-658. 
Muller, E.B., Lin, S., Nisbet, R.M., 2015. Quantitative adverse outcome pathway analysis of hatching in zebrafish with $\mathrm{CuO}$ nanoparticles. Environ. Sci. Technol. 49, 11817-11824.

Naatz, H., Lin, S., Li, R., Jiang, W., Ji, Z., Chang, C.H., Köser, J., Thöming, J., Xia, T., Nel, A.E., Mädler, L., Pokhrel, S., 2017. Safe-by-design CuO nanoparticles via Fe-doping, $\mathrm{Cu}-\mathrm{O}$ bond length variation, and biological assessment in cells and zebrafish embryos. ACS Nano 11, 501-515.

Nel, A., Xia, T., Meng, H., Wang, X., Lin, S., Ji, Z., Zhang, H., 2012. Nanomaterial toxicity testing in the $21^{\text {st }}$ century: use of a predicted toxicological approach and high-throughput screening. Accounts Chem. Res. 46, 607-621.

Ong, K.J., MacCormack, T.J., Clark, R., Ede, J.D., Ortega, V.A., Felix, L.C., Dang, M.K.M., Ma, G., Fenniri, H., Veinot, J.G.C., Goss, G.G., 2014. Widespread nanoparticle-assay interference: implications for nanotoxicity testing. PLoS One 9, e90650.

Ong, K.J., Zhao, X., Thistle, M.E., MacCormack, T.J., Clark, R., Ma, G., Martinez-Rubi, Y., Simard, B., Loo, J.S., Veinot, J.G.C., Goss, G.G., 2014. Mechanistic insights into the effect of nanoparticles on zebrafish hatch. Nanotoxicology 8, 295-304.

Peng, C., Shen, C., Zheng, S., Yang, W., Hu, H., Liu, J., Shi, J., 2017. Transformation of $\mathrm{CuO}$ nanoparticles in the aquatic environment: influence of $\mathrm{pH}$, electrolytes and natural organic matter. Nanomaterials 7, 326.

Peterson, R.H., Martin-Robichaud, D.J., 1986. Perivitelline and vitelline potentials in teleost eggs as influenced by ambient ionic strength, natal salinity, and electrode electrolyte; and the influence of these potentials on cadmium dynamics within the egg. Can. J. Fish. Aquat. Sci. 43, 1445-1450.

Santore, R.C., Di Toro, D.M., Paquin, P.R., Allen, H.E., Meyer, J.S., 2001. Biotic ligand model of the acute toxicity of metals. 2. Application to acute copper toxicity in freshwater fish and Daphnia. Environ. Toxicol. Chem. 20, 2397-2402.

Shaw, B.J., Al-Bairuty, G.A., Handy, R.D., 2012. Effects of waterborne copper nanoparticles and copper sulphate on rainbow trout, (Oncorhynchus mykiss): physiology and accumulation. Aquat. Toxicol. 116-117, 90-101.

Shaw, B.J., Liddle, C.C., Windeatt, K.M., Handy, R.D., 2016. A critical evaluation of the fish early-life stage toxicity test for engineered nanomaterials: experimental modifications and recommendations. Arch. Toxicol. 90, 2077-2107.
Shephard, K.L., 1989. The effects of mucus and mucilaginous materials on ion-distributions at epithelial surfaces. Symp. Soc. Exp. Biol. 43, 123-130.

Sørensen, S.N., Lützhøft, H.-C.H., Rasmussen, R., Baun, A., 2016. Acute and chronic effects from pulse exposure of $D$. magna to silver and copper oxide nanoparticles. Aquat. Toxicol. 180, 209-217.

USEPA, 2007. Aquatic Life Ambient Freshwater Quality Criteria - Copper EPA-822-R-07-001. United States Environmental Protection Agency Office of Water 4304T, Washington DC.

Vicario-Parés, U., Castañaga, L., Lacave, J.M., Oron, M., Reip, P., Berhanu, D., Valsami-Jones, E., Cajaraville, M.P., Orbea, A., 2014. Comparative toxicity of metal oxide nanoparticles $\left(\mathrm{CuO}, \mathrm{ZnO}\right.$ and $\left.\mathrm{TiO}_{2}\right)$ to developing zebrafish embryos. J. Nanopart. Res. 16, 2550.

Vicario-Parés, L., Lacave, J.M., Reip, P., Cajaraville, M.P., Orbea, A., 2018. Cellular and molecular responses of adult zebrafish after exposure to $\mathrm{CuO}$ nanoparticles or ionic copper. Ecotoxicology 27, 89-101.

Vignati, D.A.L., Ferrari, B.J.D., Dominik, J., 2007. Laboratory-to-field extrapolation in aquatic sciences. Environ. Sci. Technol. 41, 1067-1073.

Wang, Z., Von Dem Bussche, A., Kabadi, P.K., Kane, A.B., 2013. Biological and environmental transformations of copper-based nanomaterials. ACS Nano 7, 8715-8727.

Zhang, J., Hua, P., Krebs, P., 2016. The influences of dissolved organic matter and surfactant on the desorption of $\mathrm{Cu}$ and $\mathrm{Zn}$ from road-deposited sediment. Chemosphere 150, 63-70.

Zhang, Y., Zang, W., Qin, L., Zheng, L., Cao, Y., Yan, Z., Yi, X., Zeng, H., Liu, Z., 2017. Water quality criteria for copper based on the BLM approach in the freshwater in China. PLoS One 12, e0170105.

Zhang, B., Chen, X., Pan, R., Xu, T., Zhao, J., Huang, W., Liu, Y., Yin, D., 2017. Effects of three different embryonic exposure modes of 2,2',4,4'-tetrabromodiphenyl ether on the path angle and social activity of zebrafish larvae. Chemosphere 169, 542-549.

Zhang, Y., Zhang, R., Sun, H., Chen, Q., Yu, X., Zhang, T., Yi, M., Liu, J.X., 2018. Copper inhibits hatching of fish embryos via inducing reactive oxygen species and down-regulating Wnt signalling. Aquat. Toxicol. 205, 156-164. 